\title{
Geriatric depression, a neglected issue.
}

\section{Belén Rivera-Corvalán ${ }^{1}$}

Population aging has been one of the most distinctive demographic phenomena of the 20th century (Patil et al., 2015). The

increase in the elderly population, both globally and in Chile, has gained great importance due to its sustained increase every year. According to data from the "World Population Prospects" Report of 2017 (Available at https://esa.un.org/unpd/wpp/Publications/Files/ WPP2017_KeyFindings.pdf), it is expected that the number of older people worldwide will double by 2050 and triple by 2100 . In Chile, the scenario is similar, according to the CASEN survey (Available in http://observatorio.ministeriodesarrollosocial.gob.cl/casenmultidimensional/casen/docs/CASEN_2015_Resultados_adultos_ mayores.pdf). by $2050,28.2 \%$ of the total population will be elderly, as opposed to only $10.2 \%$ in the year 2000 .

Thus, there is an urgent need to observe the characteristics of this population and identify possible elements that could deteriorate the aging process. Within this need is the high prevalence of geriatric depression, which is one of the main causes of disability in the elderly. It is expected that by the year 2020 , geriatric depression will be the second cause of morbidity and mortality after heart diseases (Kennedy, 2015; Mahmoud et al., 2016).

Some of the main risk factors that are associated with the manifestation of geriatric depression are: belonging to the female gender (Chang et al., 2016; Salgado \& Wong, 2007; Salazar et al., 2015; Torres et al., 2015); educational attainment; poor social support and scarce social participation (Segura-Cardona et al., 2015); perception of Ioneliness (Alpass \& Neville, 2003); and the multiplicity of ways in which grieving processes manifest themselves (Kennedy, 2015). Physical risk factors include the following: difficulties in expedited locomotion and consequently a lack of autonomy (Campos et al., 2004), cognitive decline (Dillon et al., 2014); high prevalence of visual disability; and finally, previous history of depression (Bradley et al., 2016).

In the face of all this, there is a double challenge. The first is for those who work and have worked directly with the older adult population. They must design interventions focused on the well being of the elderly population, contextualized to their needs, characteristics, and contingencies. A failure to do so will increase the perception that the elderly population is not heard. The second challenge is for all of us who still observe aging as an uncertain and long-term future. We must
Affiliations: ${ }^{1}$ Fundación Kimntrum, Chile.

Corresponding author: Belén Rivera Corvalán. Beltrán Mathieu 143A, Concepción. Phone: 56-996796481.

E-mail: briverac@kimntrum.org

Conflict of interests: None.

Acknowledgements: None.

doi: $10.32457 / \mathrm{ijmss} .2018 .013$. 
disregard the preconception of aging as a personal and passive process, and instead view it as a social and active process. Every elder has a rich experience that brings us the opportunity to build on our own roots. I believe that the approach to geriatric depression and other geriatric illnesses should be an instance of selfreflection of our own responsibilities, since we can generate practical and innovative interventions.

\section{REFERENCES}

Alpass FM, Neville S. Loneliness, health and depression in older males. Aging Mental Health 2003;7(3):212-216.

Bradley B, Backus D, Gray E. Depression in the older adult: What should be considered? Mental Health Clin. 2016;6(5):222-228.

Campos J, Ardanaz J, Navarro A. Depresión en pacientes de edad avanzada. Dos ámbitos: un centro sociosanitarioy un programa de soporte domiciliario. Rev Española Geriatria Gerontol. 2004;39(4):232-9

Chang SC, Pan A, Kawachi I, Okereke OI. Risk factors for late-life depression: A prospective cohort study among older women. Prev Med. 2016;91:144-151.

Dillon C, Tartaglini MF, Stefani D, Salgado P, Taragano FE, Allegri RF. Geriatric depression and its relation with cognitive impairment and dementia. Arch Gerontol Geriatrics 2014;59(2):450-456.

Kennedy GJ. Geriatric depression: A clinical guide. USA: Guilford Publications, 2015.

Patil SD, Udayar SE, Shannawaz M. A study of depression level among elderly people in the rural area of Bijapur, India. J Evol Med Dent Sci. 2015;4(30):51545160.

Salazar AM, Reyes MF, Plata SJ, Galvi P, Montalvo C, SánchezE. Prevalencia y factores de riesgo psicosociales de la depresión en un grupo de adultos mayores en Bogotá. Acta Neurol Colomb. 2015;31(2):176-183.

Salgado VN, Wong R. Género y pobreza: determinantes de la salud en la vejez. Salud Publ Mex. 2007;49:s515-s521.

Segura-Cardona A, Cardona-Arango D, SeguraCardona Á, Garzón-Duque M. Risk of depression and associated factors in older adults. Antioquia, Colombia. 2012. Rev Salud Publ. 2015;17(2):184-194.

Torres HML, Sepúlveda YL, Aguilar JLV, Pérez RH. Factores psicosociales que inciden en la depresión del adulto mayor. Medimay 2015;21(1):65-74. 